\title{
The Multiplier Effect of Buying Local Gastronomy: Case of Sundanesse Restaurant
}

\author{
D. Turgarini , Muhammad Baiquni ${ }^{1}$, E. Harmayani ${ }^{3}$ \\ ${ }^{1}$ University Education of Indonesia Bandung \\ ${ }^{2,3}$ University of Gadjah Mada
}

Corresponding author: dewiturgarini@upi.edu

\section{ARTICLE INFO}

Received

05 January 2018

Accepted

14 March 2018

Available online

30 March 2018
Bandung is one of the cities in Indonesia which has a gastronomic diversity represents Sundanese culture as its original inhabitants. This capital city of West Java province has a lot of culture, history, and archeologyicons that are nuanced Sunda, and Colonial. Therefore, the city can be said as the city of heritage landmark (heritage-city), and gastronomical attractions can be integrated as Gastro-city. Currently the local food of Sundanese has many variants but the level of attractiveness of the food is still considered insufficient. Research was designed to find a decent meal variant proposed as a superior food; and find out what food variants as the main attraction of the city as well as to assess multiplier effect of buying local gastronomy. Both are expected to answer a question of what is base for the economic development of Bandung as Gastro city. It is also interesting to find out the multiplier effect of buying local gastronomy especially in Sundanese restaurant. The method used is descriptive exploratory study, also conducted professional assessment. Data collecting technique were observation, interviews, and examination of documents. Data was analysed using descriptive exploratory approach. The results showed that the Sundanese have a tourist attraction with the potential of the existence of 74 species featured menu consisting of appertizer, maincourse, dessert and drink as trademark. The food appeared in 24 ceremonies as a vibrant cultural event in the life cycle of Sunda tribe who live in the city of Bandung. The tourists also can enjoy a diverse featured menu in the 145 Sundanese restaurant in Bandung city. The value of the multiplier effect of tourist expenditure during the year amounting to 1,286 times that of the developing tourist spending.

Keywords: Gastronomy, Sundanese, Restaurant, Multiplier Effect, Tourist Attractions

\section{Introduction}

\section{Background}

The tourism industry is one of the largest industries in the world with the global economic contribution, reaching nearly seven trillion dollars in 2013. The direct economic impact of the industry, including accommodation, transportation, entertainment and attractions, is around 2.2 trillion US dollars. Major cities in the world are utilizing its assets to attract foreign exchange from tourists to visit the region. The situation of the global tourism also showed that about $30 \%$ of there venues derived from gastronomic tours, 
$40 \%$ of tourist expenditure is food and drinks, and $50 \%$ of revenue comes from the restaurant rating (UNWTO, 2012; Ministry of Tourism, 2015). Currently, there is a demand in the food tourism is becoming an important sector of the tourism industry.

In recent years, the food has gained recognition from the government, business, and academia as an integral part of the tourism product. An understanding of the food was also shifted from simply a product differentiator for tourism destinations (distinctive competitiveness). Local food is an important element that can help to create new experiences for tourists and increase the attractiveness of the destination.

Consumption of food turned out to be an integral aspect of the experience traveled, not just a matter of taste and presentation, but also by a sense of enjoying the place. It can almost be said of all to eat. Local food is a fundamental component of the destination attributes, add rich attractions and the overall travel experience (Symons, 1999). This is what makes food become an important constituent of the production and consumption of tourism. When you see the following definitions, it seems undeniable that the food can be a tourist attraction, i.e. (i) Journey in which there is an appreciation and local or regional food consumed, (ii) Travel with the main purpose of enjoying food, and drinks as a travel experience or to attend a specific culinary activities such as cooking schools, visit the places of production of food or drink, folk market, or enjoy the food at various places that provide them (taste trail), and (iii) The unique experience of eating and drinking

Thus it is clear that the food is not only a travel category in tourism but also an opportunity for destinations and the industry to gain competitive side. Surely culinary tourism can improve its competitiveness, must be supported by the resources eternal, it is difficult to be imitated and replaced (Porter, http://ojs.unud.ac.id/index.php/eot
1985; Prahalad and Hamel, 1990; Barney, 1991; Peteraf, 1993; Grant, 1999; Barney, Wright and Ketchen Jr, 2001).

\section{Objectives of the study}

The objectives of this study are:

1. Develop priority Sundanese foods featured in Bandung city.

2. Describe Bandung as a gastronomi city

3. Explain the multiplier effect to the purchase of Sundanese food to people in Bandung city.

\section{Literature Review}

\section{Local Gastronomy as Tourism Attraction}

The multiplier effect is the amount of local economic activity that is triggered by the purchase of anyone item (Swenson, 2009). Community economics tells us that the more money circulates in a defined region, and the faster itcirculates, the more income, wealth and jobs it creates (Shuman and Hoffer, 2007). Therefore, the development of tourist attractions is needed to create it. One being to be excellent for Indonesia is a local gastronomy development as a tourist attraction.

\section{Multiplier Effect}

Leri (2011) cites Manacika (2010) states that the multiplier effect of tourism is based on relationships forming various sectors of the economy are interrelated, and dependent on the local economy. Therefore, any change in the level of tourist spending, as one of the sectors forming the economy, will affect the industrial goods, and services. Every tourist spending affect the level of expenditure (output), value added, wages/ salaries, employment (employment), the receptionstate (government revenue), and the balance of payments. The ratio change any of the above variables to changes in final demand (in this case the expenditure by tourists) called the multiplier or multiplier. 
According Glasson (1990), the multiplier effect is an activity that can spur the emergence of other activities. Based on this theory can be explained that the tourism industry will drive other industries as supporters. The main component of the tourism industry is a major tourist attraction in the form of destinations and tourist attractions, hotels, restaurants and local transport. While supporting components, include industries in the fields of transport, food, and beverages, banking,or even manufacturing. Everything can be driven from the tourism industry.

Every dollar spent rupiah or tourists are not going to stop at one point, but will continue to spin even going up to the sectors glance look shave nothing to do with the tourism sector. According Yoeti (2008) the successful development of tourism as an industry can be seen from how the influence of US dollars spent 1 rating to the local economy. One thing to keep in mind that multiplication (turn - over or multiplier effect) that occur are not the same, but vary from one sectorto another.

Leri (2011) illustrates the rating for a destination's doing various expenditures (consumption), such as for accommodation, food, and beverage, travel, see the cultural attractions, purchase souvenirs and others. This expenditure will be "captured" by sectors of the economy, so it into income sectors of the economy. This is called a direct effect (direct effects) expenditure by tourists. However, the increase in income sector sof the economy increased the demand input derived from the output of other economic sectors such as agriculture, industry, handicraft industry, transportation, and soon. Thus, the increase in in come sectors of the economy will drive increased productivity sectors of the economy.

Increased output of the economic sectors of production will further increase the remuneration of factors of production used in the production process, thus increasing the http://ojs.unud.ac.id/index.php/eot income owners of production factors. Furthermore, the increase in income of factors will drive increased revenue owners of production factors, namely household, sand companies. This is called indirect effects (indirect effects) expenditure by tourists. The increase in household in come or the community will encouragepublic consumption, further encourages other people's income increase, and expand employment opportunities. This is called the effects driven (induced effects) of tourist expenditure. Indirect effects, and induced effects are called secondary effects, and multiplier effects (multiplier effects) rating measures the total effects (directs plus secondary) resulting from additional tourist spending.

Increased production activities of economic sectors related directly or indirectly to tourism will create, and expand employment. This is called the link age creation of employment opportunities (employment linkages). Furthermore, it will increase the remuneration of factors of production used in the production process, thus increasing the income owners of production factors. More simply, the multiplier effect is illustrated as follows:

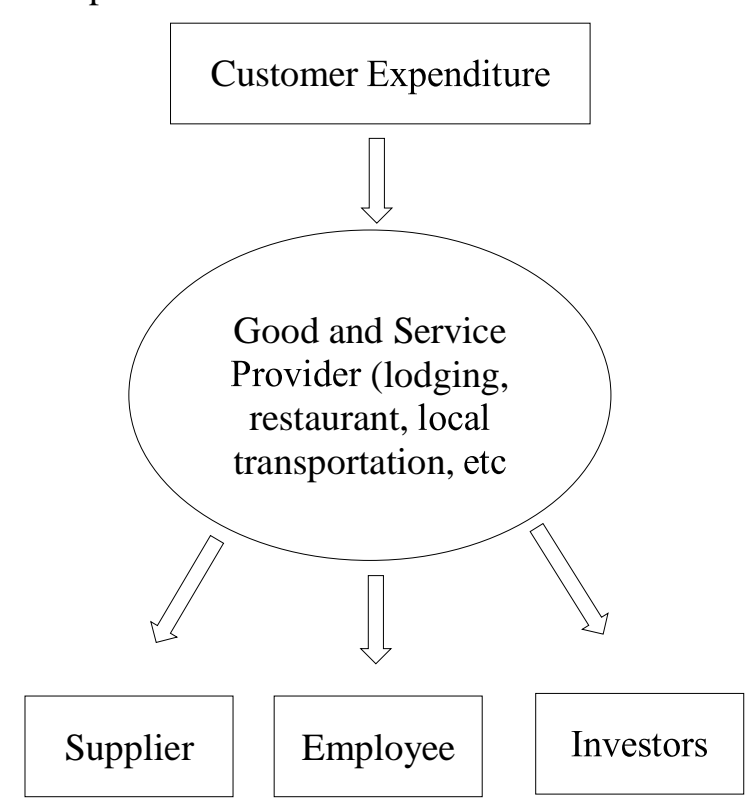

Source: Mazidah, Nugroho and Bathara (2016) 
Spending visitors or tourists will be utilized by service providers, workers, and investors to develop their business. Telfer and Sharpley (2008) illustrated the multiplier effect as follows. From the above explanation, the multiplier effect of tourism can be regarded as money in the development of local communities as a result of the spending by tourists. The larger the ratio of money circulating in the community the greater the value of the multiplier. End users of goods and services is domestic tourism, ie domestic tourists, workers, civil servants, businessmen, farmers, ranchers and so on. Similarly, government spending is considered as the enduser.

\section{Methodology}

The methods used to inventory the impact of tourism on the local economy is to conduct field observation and desk study. Desk study conducted by using a variety of secondary data obtained statistical data. The use of photos is done as a way to strengthen the narrative do. Inventory carried out on various professions and business activities arising from the site. To calculate the multiplier effect was undertaken by calculating the coefficient of multiplier effect of tourism which is formulated as follows;

Mark :

$$
\mathrm{k}=\mathrm{A} \frac{1}{1-\mathrm{BC}}
$$

$\mathrm{k}=$ konstansta income multiplier

(Keysnesian Local Income Multiplier)

$A=$ percentage of the initial tourist spending

$\mathrm{B}=$ the percentage of business revenue (layer

1) which is spent locally economic

$\mathrm{C}=$ the percentage of supplier revenue and salaries is spent locally economic

Local Keysnesian Income Multiplier Values have the following criteria:

1. If the values are less than or equal to zero $(<0)$, then the tourist site has not been able to provide economic impact on tourism activities.

2. If the values are between zero and one $(0<x<1)$, then the tourist site still has a value of low economic impact.
3. If the values are greater than or equal to one (>1), then the tourist sites have been able to provide economic impact on tourism activities.

Multiplier score resulted by drafting the proportion of spending by tourists in destinations during one year. This proportion is based on observations and interviews with travelers. The calculations of these travelers' proportions determine spending patterns in each destination.value multiplied by the proportion of the total amount spent by tourists during the year.This value is the value of the direct effect or spending Layer 1.

In direct effects are calculated based on the proportion of expenditure on layer1, and based on the forecasts pending needs of businesses in layer 1 . The result of the calculation is the value of the in direct effect. Calculations performed multiplier effect until this stage. Tails are not included in the calculation because the amount is very small and its distributionis very broad.

The study was conducted in one wellknown restaurant Sunda in Bandung, namely Bancakan at Trunojoyo Street No. 62 Bandung, West Java, Indonesia. The study was conducted for 2 weeks on September 2016.

\section{Result and Discussion}

\section{Profile Top Five Sundanesse Gastronomy}

Type of main Sundanese gastronomy can be seen in the Table 1.

Table 1. Main Sundanese Gastronomy

\begin{tabular}{|c|c|c|c|c|}
\hline No & $\begin{array}{l}\text { Sundanese } \\
\text { Menu }\end{array}$ & Type & Uniqueness & $\begin{array}{l}\text { Time } \\
\text { To Eat }\end{array}$ \\
\hline 1 & $\begin{array}{l}\text { Ayam } \\
\text { Goreng } \\
\text { Laja } \\
\text { (Gala } \\
\text { ngal } \\
\text { Fried } \\
\text { Chic } \\
\text { ken) }\end{array}$ & $\begin{array}{l}\text { Main } \\
\text { Course }\end{array}$ & $\begin{array}{l}\text { The fried chicken } \\
\text { has authentic } \\
\text { flavor from } \\
\text { delicious aroma } \\
\text { grated galangal, } \\
\text { shallots, garlic } \\
\text { and turmeric. }\end{array}$ & $\begin{array}{l}\text { Lunch } \\
\text { and } \\
\text { Dinner }\end{array}$ \\
\hline
\end{tabular}




\begin{tabular}{|c|c|c|c|c|}
\hline 2 & Colenak & Dessert & $\begin{array}{l}\text { Unique from } \\
\text { aroma and taste of } \\
\text { fermented cassava } \\
\text { grilled and } \\
\text { sprinkled with } \\
\text { brown sugar } \\
\text { syrup, grated } \\
\text { coconut and slices } \\
\text { of jackfruit. }\end{array}$ & $\begin{array}{l}\text { Lunch } \\
\text { and } \\
\text { Dinner }\end{array}$ \\
\hline 3 & Surabi & Dessert & $\begin{array}{l}\text { This cake made of } \\
\text { rice flour dough, } \\
\text { coconut milk, salt } \\
\text { baked in a mold } \\
\text { round unanimous } \\
\text { soil. This cake } \\
\text { then after being } \\
\text { cooked then } \\
\text { sprinkling oncom } \\
\text { or brown sugar } \\
\text { syrup. }\end{array}$ & $\begin{array}{l}\text { Breakf } \\
\text { ast, } \\
\text { Lunch } \\
\text { and } \\
\text { Dinner }\end{array}$ \\
\hline 4 & Bajigur & Beverage & $\begin{array}{l}\text { Sundanese } \\
\text { traditional drink } \\
\text { made from } \\
\text { coconut milk and } \\
\text { brown sugar } \\
\text { solution and } \\
\text { served with fruit } \\
\text { kolang kaling } \\
\text { from sap tree }\end{array}$ & $\begin{array}{l}\text { Breakf } \\
\text { ast, } \\
\text { Lunch } \\
\text { and } \\
\text { Dinner }\end{array}$ \\
\hline 5 & $\begin{array}{l}\text { Tutug } \\
\text { Oncom }\end{array}$ & $\begin{array}{l}\text { Complet } \\
\text { e } \\
\text { Menu }\end{array}$ & $\begin{array}{l}\text { tutug oncom is } \\
\text { typical Sundanese } \\
\text { food is rice mixed } \\
\text { oncom and } \\
\text { flavored with } \\
\text { onion, garlic and } \\
\text { kencur. Aroma } \\
\text { oncom made from } \\
\text { soy or nuts mixed } \\
\text { pulp cassava flour } \\
\text { then fermented. } \\
\text { Then other unique } \\
\text { aroma is of } \\
\text { kaemfria galanga. }\end{array}$ & $\begin{array}{l}\text { Lunch } \\
\text { and } \\
\text { Dinner }\end{array}$ \\
\hline
\end{tabular}

Source : Data Procesed, 2017

Restaurants in Bandung was growth, as shown by the presence of Sundanese restaurant, restaurant with Indonesian menu from 34 other provinces, as well as foreign restaurant. Based on the research results through the study of literature, observation, interviews and expert meeting, there was founded the amount of growth Sundanese restaurant, other Indonesian, and foreign restaurant tables created by researchers as a data culinary tourism, especially in the future. The spread of restaurants in the city is currently in central Bandung was the highest concentration of growth. This is evident from the results of observations and interviews conducted during the three months since the month of December 2016 until April 2017, the researchers found the presence of 990 restaurants in the city. This can be seen in the following table:
Table 2. Distribution of Sundanese, other Indonesian and Foreign Restaurant in 2017

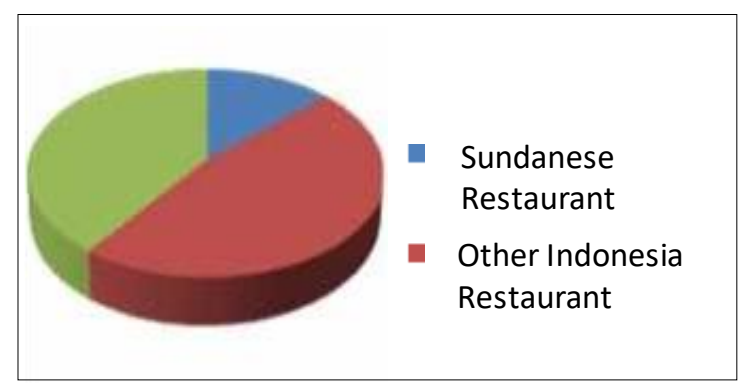

Source : Data Procesed 2015-2017

Based on the findings obtained from the data contained 145 Sundanese Restaurant. This is a restaurant that serves food and drinks typical Sundanese as native of Bandung city. While the existence of restaurant from 33 other provinces in Indonesia, amounted to 517 restaurants. The growth was recorded presence of foreign restaurants totaled 438 units Restaurant. It is clear that the growth of Sundanese restaurant only $13.2 \%$, than other Indonesian restaurant $47 \%$, and the foreign restaurants $39.8 \%$. Therefore necessary to develop a quality restaurant Sunda restaurant featuring a menu of food and drinks as native restaurant in Bandung city. In detail the deployment of five restaurants in Bandung city region, can be seen in the following table:

Table 3. The Growt of Sundanese, Indonesian and Foreign Restaurant in Bandung City in 2017

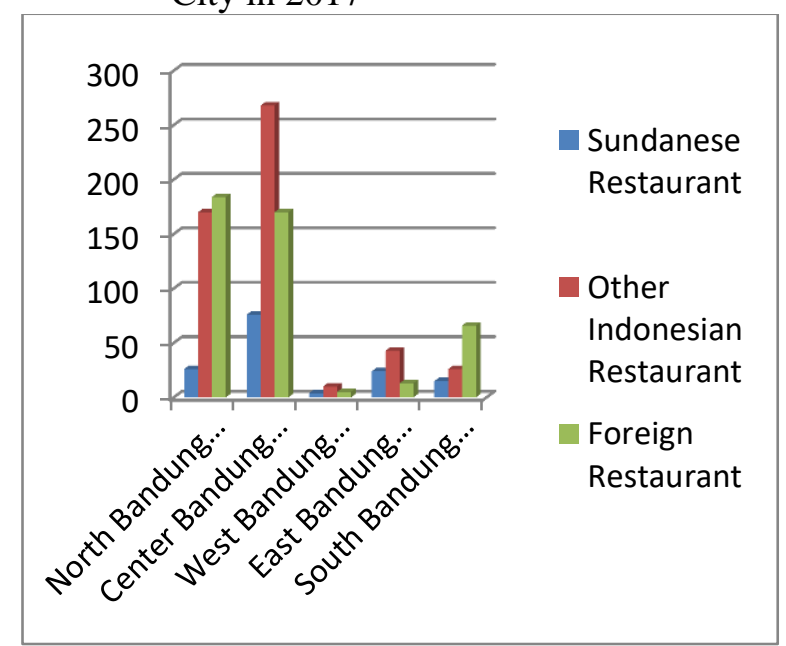

Source : Data Processed 2015-2017 
The results showed first in the North Bandung region totaling 380 restaurants, consisting of 26 restaurants Sunda, 170 restaurants Indonesia, and 184 foreign restaurants. Both the restaurant and food businesses in the Central Bandung region, amounting to 404, consisting of 76 restaurants Sunda, 268 restaurants Indonesia, and 170 international restaurants. All three restaurants and food businesses in the South Bandung region, which is amounts to 107 , consisting of 15 restaurants Sunda, 26 restaurants Indonesia, and 66 international restaurants. Fourth restaurants and food businesses in the West Bandung region, amounting to 19 , consisting of 4 restaurants Sunda, 10 restaurants Indonesia, and 5 restaurants abroad. Last restaurants and food businesses in the East Bandung region which is numbered 80 , consisting of 24 restaurants Sunda, 43 restaurants Indonesia, 13 restaurants abroad. The growth of the highest restaurant in the city of Central Bandung amounting 404 restaurants, and the lowest was in West Bandung with the number of restaurants 19 . Then based on the findings of the field is also known that the restaurant was already registered and listed in Bandung Tourism Office, and Organization of Hotels and Restaurants, and Cafes and Restaurants Association in Bandung city in 2014 amounted to 154 restaurants $(15.6 \%)$ that are a fraction of the 990 restaurants located in five regions mentioned above. There for restaurant industry in Bandung city must make awarenes to developed their standar was being made of Indonesian goverment to achieved the national and internastional standard of Restaurant operation. This is very important to make an excellent service to the tourist, and make Bandung city as destination of gastronomy tourism in Indonesia.

\section{Multiplier Effect of Sundanese Gastronomy}

\section{Direct Effect}

Direct effect are the benefits felt by the local community in the form of income received by the restaurant. The resulting economic effects, measured from the restaurant overall spending for capital needs and consumption. Some of the assumptions used to establish the direct impact of tourist expenditures as follows;
1. Number of Sundanese restaurants are 26 restaurant

2. Visitors average restaurant every day is 250 people

3. Any tourists spend an average of Rp. 200.000, - each visit

4. Spending by foreign tourists and domestic tourists are considered equal

5. Benchmarking spending on the direct impact has been proportionally based on interviews and field observation

Spending patterns Sundanese restaurants in Bandung consist of expenditures for salaries / wages, income, raw materials, taxes and rents and other overhead. The result of the calculation of expenditure shows that the direct effect of this distribution figures obtained for 0.408 , which means that as much as $40.8 \%$ percent of the money received outstanding restaurant Sunda back in the community. This value is relatively low and therefore the component of profit, tax and overhead that did not circulate (leakage).

\section{Indirect Effect}

Indirect effects are the benefits felt by the local community in the form of income received by the beneficiary communities I of restaurants. The resulting economic effect, covering a larger area than the immediate effects. Some of the assumptions used to establish the impact of indirect expenditures rating as follows.

1. Revenue community of people who enjoy spending the direct effect is Rp. 105.477 billion.

2. Spending on these indirect effects dikatagori in two types of expenditures are for capital goods and for consumption

\section{Induced Effect}

Indirect spending patterns consist of expenditures for working capital and expenditures for consumption. Results count of distribution of expenditure layer 2 shows the value of 0.546 , this means that as many as $54.6 \%$ of expenditures layer of the recirculated in the community. Induced effects that occur are spending the results obtained from the spending phase II. This effect occurs is spending beneficiaries of the spending phase 
II to beneficiaries in the phase III and beyond. This follower effect is a primary sector such as farmers, ranchers, home industries, and so on. At this stage in restaurant spending more is because relatively little.

\section{Multiplier Effect}

Multiplier Effect was calculated by counting direct effect, and indirect effects that occur at the destination. Count Keysnesian Local Income Multiplier that uses components of direct and indirect effects. By using the value of the direct and indirect effects of the above it can be seen the value of the multiplier as follows.

Table 3. Source of Multiplier Effect

\begin{tabular}{|c|c|c|c|c|c|}
\hline $\begin{array}{l}\mathrm{N} \\
\mathrm{o}\end{array}$ & Impact Item & $\begin{array}{c}\text { Value } \\
\text { EL }\end{array}$ & $\begin{array}{l}\text { Value } \\
\text { ETL1 }\end{array}$ & $\begin{array}{l}\text { Value } \\
\text { ETL2 }\end{array}$ & $\mathrm{ME}$ \\
\hline I & $\begin{array}{l}\text { Tourist } \\
\text { Expenditure }\end{array}$ & 1 & & & \\
\hline II & $\begin{array}{l}\text { Destination I } \\
\text { Expenditure }\end{array}$ & & 0,408 & & \\
\hline \multirow[t]{2}{*}{ II } & $\begin{array}{l}\text { Destination II } \\
\text { Expenditure }\end{array}$ & & & 0,647 & \\
\hline & Total Value & 1 & 0,408 & 0,647 & $\begin{array}{r}1,2 \\
86\end{array}$ \\
\hline
\end{tabular}

From the table it can be seen that the value of the multiplier effect of tourist expenditure during the year amounting to 1,286 times that of the developing tourist spending. The amount of money is a result of the development expenditure in the Sundanese restaurant in Bandung. Income multiplier is generally an additional measure of income (income, payroll, and benefits) in the economy as a result of an increase in tourist expenditure. Thus the Sundanese restaurant in the city of Bandung contributed Rp. 135.6 per year towards the development of Bandung as a city of gastronomy.

\section{Conclusion}

It can be concluded that:

1. Food featured Bandung as gastrocity dominated by full food and beverage

2. The number of Sundanese restaurants in Bandung shows some optimistic

3. The restaurant Sunda in Bandung contributed Rp. 135.6 per year towards the development of Bandung as a city of gastronomy

\section{References}

Barney, J. (1991) 'Firm resources and sustained competitive advantage', Journal of management. Sage Publications Sage CA: Thousand Oaks, CA, 17(1), pp. 99-120.

Barney, J., Wright, M. and Ketchen Jr, D. J. (2001) 'The resource-based view of the firm: Ten years after 1991'. Elsevier.

Glasson, J. (1990) Pengantar Perencanaan Regional. Jakarta: LPFE-UI.

Grant, R. M. (1999) 'The resource-based theory of competitive advantage: implications for strategy formulation', in Knowledge and strategy. Elsevier, pp. 323.

Leri, I. A. A. (2011) 'Dampak Pengeluaran, Wisatawan Terhadap Perkembangan Sektor ekonomi di Provinsi Bali'. Denpasar. Program Magister Program Studi Kajian Pariwisata Program Pascasarjana Universitas Udaya Denpasar, Tidak dipublikasikan.

Manacika, I. K. (2010) Dampak Pariwisata Terhadap Permintaan Output Sektor Pertanian di Provinsi Bali. Universitas Udayana.

Mazidah, N., Nugroho, F. and Bathara, L. (2016) 'The Multiplier Effect of the Gandoriah Beach Marine Tourism to the Coastal Community of Kelurahan Pasir, Central Pariaman District, Pariaman City West Sumatra Province', Jurnal Online Mahasiswa (JOM) Bidang Perikanan dan Ilmu Kelautan, 3(2), pp. 1-12.

Ministry of Tourism (2015) Rencana Srategis Kementerian Pariwisata 2015-2019. Jakarta: Kementerian Pariwisata.

Peteraf, M. A. (1993) 'The cornerstones of competitive advantage: A resource-based view', Strategic management journal. Wiley Online Library, 14(3), pp. 179191. 
Porter, M. (1985) Competitive Advantage: creating and sustaining superior Performance. New York: NY: Free Press.

Prahalad, C. K. and Hamel, G. (1990) 'The core competence of the corporation.', Harvard Business Review. Harvard Business School Publication Corp., 68(3), pp. 79-91.

Shuman, M. and Hoffer, D. (2007) Leakage Analysis of the Martha's Vineyard Economy: Increasing Prosperity Through Greater Self-Reliance. Martha's Vineyard Commission.

Swenson, D. (2009) 'Investigating the potential economic impacts of local foods for Southeast Iowa'.

Symons, M. (1999) 'Gastronomic authenticity and sense of place', in CAUTHE 1999: Delighting the Senses; Proceedings from the Ninth Australian Tourism and Hospitality Research Conference. Bureau of Tourism Research, p. 401.

UNWTO (2012) 'UNWTO Annual Report'. New York.

Yoeti, O. A. (2008) 'Ekonomi Pariwisata', Introduksi, Informasi, Implementasi. Jakarta [ID]: Kompas, 292. 